\title{
Development of A Disaster Attitude Scale and Assessment of University Students' Attitudes Towards Disasters
}

\author{
Afet Tutum Ölçeği Geliştirilmesi ve Üniversite Öğrencilerinin Afetlere Karşı \\ Tutumlarının Değerlendirilmesi
}

\author{
Ayça Hatice TÜRKAN ${ }^{1}$ \\ İbrahim KILIÇ² \\ Murad TIRYAKIOĞLU3
}

\author{
https://orcid.org/0000-0002-4375-9733 \\ https://orcid.org/0000-0003-0595-8771 \\ https://orcid.org/0000-0002-1874-0678
}

\begin{abstract}
Humanity is exposed to numerous disasters all around the world. Both natural and man-made disasters might lead to very important economic and social consequences and might pose a significant threat to public health and its future. Therefore, the attitudes of individuals before, during and after a possible disaster are worth considering. This study aims to develop a scale to measure attitudes towards disasters by considering three dimensions of attitude: cognitive, affective and behavioural. A survey-based study was carried out on a sample of 787 undergraduates at Afyon Kocatepe University in Turkey. A five-point Likert scale including 23 items was used to quantify students' attitudes. The results obtained from the survey revealed a high level of affective attitudes and a low level of behavioural attitudes among the university students. Moreover, affective and behavioural attitudes differed based on the students' gender and their study programme. Attitudes towards disasters are not at the required level according to these measurements made at the local level. It is necessary to produce and implement policies in the scope of preparation for a possible crisis.
\end{abstract}

Keywords: Attitude scale, disaster, earthquake, public health.

JEL Codes: C10, C83, 013

\begin{abstract}
ÖZET
İnsanoğlu, dünyanın dört bir yanında birçok afete maruz kalmaktadır. Hem doğal hem de insan kaynaklı afetler, önemli ekonomik ve sosyal sonuçlara yol açabilmekte; halk sağlığı ve geleceği için önemli bir tehdit oluşturabilmektedir. Bu yüzden bireylerin olası bir afet öncesi, sırası ve sonrası tutumları incelenmeye değer bir konudur. Bu çalışma, tutumun bilişsel, duyuşsal ve davranışsal olan üç boyutunu dikkate alarak, afetlere yönelik tutumları ölçmek için bir ölçek geliştirmeyi amaçlamaktadır. Afyon Kocatepe Üniversitesi'nde 787 lisans öğrencisi üzerinde ankete dayalı bir çalışma yapılmıştır. Öğrencilerin tutumlarını ölçmek için 23 maddeden oluşan beşli Likert ölçeği kullanılmıştır. Araştırmadan elde edilen sonuçlar, üniversite öğrencileri arasında yüksek düzeyde duyuşsal tutum ve düşük düzeyde davranışsal tutum olduğunu ortaya koymuştur. Ayrıca, duyuşsal ve davranışsal tutumlar, öğrencilerin cinsiyetleri ve çalışma programlarına göre farklılaşmaktadır. Afetlere yönelik tutumlar, yerel düzeyde yapılan bu ölçümlere göre arzu edilen düzeyde değildir. Olası bir kriz için hazırlık kapsamında politikalar üretmek ve uygulamak gerekmektedir.
\end{abstract}

Anahtar Kelimeler: Tutum ölçeği, afet, deprem, halk sağlığı.

JEL Kodları: C10, C83, 013

'Asst. Prof., Afyon Kocatepe University, Faculty of Science and Literature, Department of Statistics, Afyonkarahisar, aturkan@aku.edu.tr

${ }^{2}$ Assoc. Prof., Afyon Kocatepe University, Faculty of Veterinary Medicine, Department of Biostatistics, Afyonkarahisar, kilicibrahim@hotmail.com

${ }^{3}$ Assoc. Prof., Afyon Kocatepe University, Faculty of Economics and Administrative Sciences, Department of Economics, 


\section{INTRODUCTION}

Natural and man-made disasters result in significant economic and social costs throughout the world. Moreover, they affect directly public health and increase fragility depending on their severity. Together with global climate change and industrial accidents, natural disasters threaten particularly women, disabled people, immigrants, minorities, children, the elderly and youth. As a natural result of this impact, the severity of physical and economic damage caused by natural disasters is higher in less-developed countries than in developed countries. Rottach (n.d.) underlined that poverty is both the cause and the result of disaster vulnerability for both nations and individual households. Therefore, the first step should be taken on the individual level in order to foster disaster awareness at the national level. However, the critical point to be considered is that poor people and underdeveloped countries have to focus on meeting the basic needs before they take measures in disaster awareness, the benefits of which would be seen in the long term.

107 million people were affected by a total of 317 natural disasters in 2014 (IFRC, 2015). 1,753 floods, 223 droughts, 1,254 earthquakes, 988 storms and 236 high-temperature events occured between 2005-2014, affecting billions of people and causing billions of dollars in economic damage. When examining the geographical distribution of the economic and social impacts of the disasters, one can observe that the less-developed and developing countries are more likely to be affected by natural disasters, and the normalisation of both economic and social activities takes a much longer time with higher costs than developed countries.

Especially being highly fragile to natural disasters, Turkey has experienced numerous disaster experiences. The damage to the environment depending on the growing industrialization increases the frequency and severity of man-made disasters in Turkey. Erzincan earthquake occurred in 1939 was a major disaster in the history of the Republic of Turkey. It caused more than 32,000 people to lose their lives according to official records. The Marmara (Kocaeli) earthquake killed nearly 17,000 people and led to an economic loss of \$12-\$19 billion, according to official records. In recent history, the Van and Simav earthquakes once again revealed the high disaster risk of Turkey, affecting significant numbers of people. Recent experiences have shown that Turkey has developed its capacity and capability for disaster emergency response and search and rescue since the 1999 Marmara earthquake. Nonetheless, disaster awareness remains inadequate among the Turkish people, except among those who have experienced disasters or whose relatives have suffered disasters.

The common attitude of all communities after the disaster is that awareness reaches the highest level immediately after the disaster but after a while this level of awareness decreases. Likewise, disaster awareness in Turkey is very high in the post-disaster period, but after a certain period of awareness, the level of awareness decreases. The underlying reason for this is that the mechanisms to keep the level of awareness at a certain level and the disaster culture to ensure the sustainability of these mechanisms are not sufficiently developed. This finding suggests that the level of individual and social preparedness and awareness must develop together.

In countries with high vulnerability to disasters such as Turkey, high levels of knowledge, awareness and preparedness of individuals about disasters ensure relatively less impact of disasters. Pre-and post-disaster behaviours and attitudes vary depending on the capacity of preparing for disasters, and the educational activities in the relevant field. In this context, it is important to examine in depth the concept of attitude. In the literature, there are numerous definitions of the concept of attitude. One of the definitions of attitude is that it comprises feelings, thoughts and behaviours towards something (Rosenberg \& Hovland, 1960; Smith, 1968; Zanna \& Rempel, 1988; Olson \& Zanna, 1993). These components are known as the ABCs of attitudes (affective, behavioural and cognitive). The affective component refers to feelings and emotions, the behavioural component to behaviours and the cognitive component to thoughts and beliefs.

Previous studies generally handled the disasters together with risk perception (Lindell \& Perry, 2003; Baytiyeh \& Öcal, 2016), preparedness (Dooley et al., 1992; Junn \& Guerin, 1996; Tierney et al., 2001) and attitudes (Honda et al., 2014; Ahayalimudin \& Osman, 2016). Examining the studies about the attitudes of the individuals related to disasters, a limited literature is discovered. Qi et al. (2003) designed a questionnaire that measures disaster perception from three aspects: disaster knowledge, disaster attitude and responding behaviour. Honda et al. (2014) developed a six-point scale to assess individuals' multidimensional attitudes about the Fukushima nuclear accident. Ahayalimudin 
and Osman (2016) explored emergency medical personnel's knowledge, attitude and practice towards disaster management using a questionnaire. Tavan et al. (2016) developed a questionnaire on the nurses' knowledge, attitude and practice of disaster preparedness. Bhat et al. (2017) designed a questionnaire to assess the level of awareness, attitudes and practices about the disaster preparedness among college students in district Ganderbal of Kashmir Valley. Pekez-Pavliško et al. (2018) designed a questionnaire including items related to attitudes (risk awareness, response to disaster), self-assessed preparedness and previous experience in order to respond or assist in mass casualty incidents in Croatia, and conducted to family physicians. Certainly, there are studies in which affective, cognitive and behavioural responses to disasters are examined in other theoretical frameworks or in the context of other constructs (Terpstra, 2011; Grimm et al., 2014; Lindholm et al., 2015). However, this study was mainly aimed at developing a scale based on the ABCs of attitudes to measure the attitudes towards disasters in Turkey using a sample of students who were considered to be representatives of future policy makers and the next generation. In the scale, the attitudes of the individuals were evaluated by considering stages of the disaster: before, during and after a disaster. Before a possible disaster, the proper attitudes had been considered regarding to the measures to prevent or minimize the damages caused by disaster. During a disaster, attitudes towards dealing with a disaster in an appropriate manner and after a disaster attitudes regarding the actions to be taken were considered. The developed scale was applied to students at Afyon Kocatepe University in Afyonkarahisar province where the earthquake risk is high.

The paper is organised as follows. First, the scale's construct validity and reliability were assessed. Second, the dimensions of the scale were compared. Third, the effects of gender and study programme on each dimension were examined. Finally, the disaster attitude level of undergraduates was determined.

\section{METHOD}

\section{PARTICIPANTS}

The participants of the study comprised 787 undergraduates pursuing different programmes at Afyon Kocatepe University in Turkey. In this framework, stratified sampling was used and the students' study programmes (natural sciences, health sciences and social sciences) were defined as strata. The sample size was calculated by the formula, $\mathrm{n}=\mathrm{s} 2 \mathrm{Z2} / \mathrm{d} 2$, as recommended by the NEA (1965) for quantitative research, assuming an infinite universe $(N>10000)$. Depending on the formula, the minimum acceptable sample size was found to be $650(s=1.30, Z=1.96, d=$ 0.10 ; s: standard deviation, Z: critical or theoretical table value for a significance level of 0.05 , d: effect size). In the determination of the unknown values in the formula, the results of the pilot study of 35 participants were used. After the pilot study, the questionnaires were distributed to 820 students. From the collected questionnaires, 33 of them were incomplete and were therefore excluded, leaving 787 questionnaires for the analyzes given in Data Analysis section.

\section{INSTRUMENT}

The questionnaire used in this study was in Turkish language, including three subscales to measure the students' attitudes towards disasters and their responses to additional demographic questions (gender and undergraduate study programmes). The scale items (i.e. statements) were written according to the structure of the attitude scale (Edwards, 1983). The affective dimension comprised items measuring fear, anxiety and worry of individuals in the event of a possible disaster. The behavioural dimension comprised items related to behavioural responses to a possible disaster and disaster measures. The cognitive dimension contained items that express ideas of individuals and also included some basic knowledge.

In the development of our scale, Delphi method was utilised by which experts are subjected to a series of questionnaires with controlled opinion feedback to collect data from a group of experts and to obtain the most reliable opinion consensus (Dalkey \& Helmer, 1963). But a two-round Delphi technique was used instead of the three-round Delphi technique, which was widely used in the literature, because the experts reached consensus after the second round. Primarily, experts were detected from official institutions operating on disasters in Turkey, relevant non-governmental organizations, engaged in research in this area and academicians working in universities in the same area. Some of the experts have been working on disasters officially, some of them voluntarily and the rest both officially and voluntarily. A total of 7 experts were contacted via email and their approvals were received for the expertise. By email, the experts were asked with open-ended questions what survey items could be asked to participants in order to determine their affective, behavioural, cognitive attitudes towards 
disasters. An item pool of 67 statements was created with the first feedback from experts (round 1). Then, the number of items was reduced to 34 with the evaluation of the information obtained by a comprehensive literature review about the disasters and by combining statements similar to each other in the item pool. The completed 34-item draft scale was sent to the experts and they were asked to rate whether or not each of the item is appropriate and to make additional relevant suggestions, if there are any (round 2). Thus, assessments were made by all experts whether the items in the scale were relevant, and whether they represented the structure to be used to measure. Consensus was established with absolute majority of agreement by experts for an item. After the second consultation round, 5 items were removed and the number of items in the item pool was reduced to 29. Then, a focus group consisting of 6 students and a pilot study of 35 participants were employed. Respondents reported that 26 out of 29 items were clear and understandable. After the two-round Delphi which was followed by a focus group discussion and a pilot study were completed, thorough discussions with Turkish experts were held for cultural and linguistic assessments of items. In the end the final draft of the scale consisting of 26 items was obtained.

This scale was applied face to face to 787 undergraduate students between May and June 2016. All students were provided a questionnaire that included the statement of informed consent, personal questions, and related scale. Participants were informed that the survey aimed to assess attitudes towards disasters, their participation was voluntary and the data would be maintained confidential. Each item of the scale was answered on a five-point Likert scale, ranging from 1 ('totally disagree') to 5 ('totally agree'). It should be noted that the questionnaire was in Turkish language, but to be included in the paper, the items were translated into English.

\section{DATA ANALYSIS}

First, the reliability and internal consistency statistics for the subscales were measured. To investigate patterns in the participants' responses to the attitude items, exploratory factor analysis (EFA) was performed using varimax rotation. Following EFA, confirmatory factor analysis (CFA) with a different sample was used to test the factor structure. A repeated measure ANOVA was performed for comparing the factors obtained from the EFA and Bonferroni test was used for paired comparisons. The independent samples $t$ test and oneway ANOVA with Tukey's honest significant difference post-hoc test were conducted to investigate whether the attitude dimensions differed depending on the gender and the study programmes of the participants.

\section{FINDINGS}

Male and female participants composed $39.4 \%$ (310) and $60.6 \%$ (477) of the sample, respectively. Their ages ranged from 18 to 26 . Of all participants, $31.8 \%$ were students of natural sciences programmes, $33.5 \%$ health sciences programmes, and $34.7 \%$ social sciences programmes.

The above-mentioned draft of the scale contained 26 items. To select items for the final version, we performed a reliability analysis. Table 1 presents the corrected item-total correlation in the first column and the Cronbach's alpha if item deleted in the second column. The corrected item-total correlation values smaller than 0.3 suggest the removal of the items from the scale (Maltby et al., 2010). Removal of items 4, 25 and 26 from the scale according to this criterion also leads to an increase in Cronbach's alpha value. The results of this procedure led to the removal of three items and in the final scale, a set of 23 items was offered to measure attitudes towards disasters. The means and standard deviations for these items are also presented in Table 1.

Initially, an EFA was conducted on the scale comprising 23 items, yielding a three-factor solution. The Bartlett's test for sphericity and Kaiser-Meyer-Olkin measure of sampling adequacy verify the factorability of data (Barlett's test of sphericity gives (approx.) $\chi^{2}=$ 7345.292, df = 253 and sig. 0.000; Kaiser-Meyer-Olkin measure of sampling adequacy is 0.888). Table 2 displays items, factor loadings, eigenvalues and total variance explained. Factor analysis was performed employing orthogonal varimax rotation, resulted in $55.273 \%$ of variance explained. The number of factors was established on the basis of those with eigenvalues greater than 1 as the selection criteria. Affective attitude made the most significant contribution to the scale, accounting for $21.004 \%$ of the variance. The second and third most significant factors were determined to be cognitive and behavioural attitudes, respectively. The factor loadings confirmed the scale's accurate assessment of the three types of attitude: affective, cognitive and behavioural. 
Table 1: The results of the reliability analysis for the subscales.

\begin{tabular}{|c|c|c|c|c|c|}
\hline Factors & Items & $\begin{array}{c}\text { Corrected } \\
\text { Item-Total Correlation }\end{array}$ & Cronbach's Alpha if Item Deleted & $\bar{X}$ & SD \\
\hline \multirow{8}{*}{ 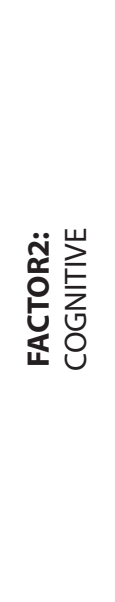 } & 11 & 0.674 & 0.815 & 3.10 & 1.08 \\
\hline & 12 & 0.670 & 0.817 & 2.94 & 1.00 \\
\hline & 13 & 0.585 & 0.826 & 2.58 & 1.10 \\
\hline & 14 & 0.246 & 0.868 & 3.60 & 1.21 \\
\hline & 15 & 0.624 & 0.821 & 2.63 & 1.18 \\
\hline & 16 & 0.662 & 0.816 & 2.69 & 1.20 \\
\hline & 17 & 0.714 & 0.809 & 2.82 & 1.17 \\
\hline & 18 & 0.518 & 0.834 & 3.57 & 1.15 \\
\hline \multirow{9}{*}{ 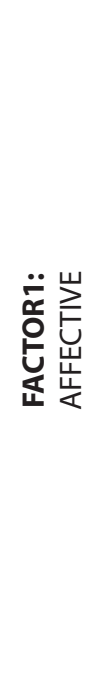 } & 19 & 0.545 & 0.820 & 3.39 & 1.33 \\
\hline & 110 & 0.409 & 0.860 & 3.70 & 1.25 \\
\hline & 111 & 0.556 & 0.819 & 3.79 & 1.20 \\
\hline & 112 & 0.530 & 0.822 & 3.68 & 1.25 \\
\hline & 113 & 0.681 & 0.807 & 3.70 & 1.19 \\
\hline & I14 & 0.734 & 0.803 & 3.83 & 1.14 \\
\hline & 115 & 0.711 & 0.805 & 3.74 & 1.18 \\
\hline & 116 & 0.600 & 0.815 & 3.77 & 1.23 \\
\hline & 117 & 0.453 & 0.829 & 3.84 & 1.18 \\
\hline \multirow{9}{*}{ 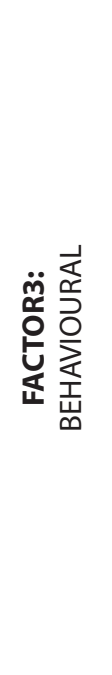 } & 118 & 0.500 & 0.789 & 2.53 & 1.17 \\
\hline & 119 & 0.575 & 0.780 & 2.28 & 1.23 \\
\hline & 120 & 0.709 & 0.764 & 1.84 & 1.16 \\
\hline & 121 & 0.651 & 0.770 & 1.80 & 1.24 \\
\hline & 122 & 0.560 & 0.781 & 1.98 & 1.29 \\
\hline & 123 & 0.602 & 0.776 & 2.31 & 1.26 \\
\hline & 124 & 0.557 & 0.783 & 2.98 & 1.14 \\
\hline & 125 & 0.168 & 0.825 & 3.98 & 1.10 \\
\hline & 126 & 0.285 & 0.824 & 3.27 & 1.56 \\
\hline
\end{tabular}

$\overline{\mathrm{X}}=$ Mean; SD=Standard Deviation 
Table 2: The results of the exploratory factor analysis.

\begin{tabular}{|c|c|c|c|c|}
\hline \multirow{2}{*}{ No } & \multirow{2}{*}{ Items } & \multicolumn{3}{|c|}{ Factor Loadings } \\
\hline & & Factor 1 & Factor2 & Factor3 \\
\hline 1 & I have a basic knowledge about disasters. & 0.072 & 0.778 & 0.079 \\
\hline 2 & $\begin{array}{l}\text { I know how to reduce and/or eliminate the risk factors related to } \\
\text { disasters. }\end{array}$ & 0.076 & 0.757 & 0.119 \\
\hline 3 & I have enough information about the family disaster plan. & 0.051 & 0.633 & 0.284 \\
\hline 5 & I have enough information about the safety of the house/dorm I live. & -0.034 & 0.718 & 0.166 \\
\hline 6 & I know what the non-structural risk factors are at home/dorm I live. & -0.053 & 0.770 & 0.147 \\
\hline 7 & $\begin{array}{l}\text { I know what I need to do to reduce the non-structural risk factors of } \\
\text { the house/dorm I live. }\end{array}$ & -0.015 & 0.804 & 0.155 \\
\hline 8 & $\begin{array}{l}\text { I know how to behave during a disaster in crowded places (shop- } \\
\text { ping centers, schools, public transport, social activity areas, etc.). }\end{array}$ & 0.100 & 0.619 & 0.150 \\
\hline 9 & The risk of experiencing a disaster in the city I live scares me. & 0.669 & -0.042 & 0.145 \\
\hline 10 & The risk of experiencing a disaster in the country I live scares me. & 0.816 & 0.035 & -0.049 \\
\hline 11 & $\begin{array}{l}\text { It makes me uneasy that necessary measures are not taken against a } \\
\text { potential disaster. }\end{array}$ & 0.663 & 0.013 & 0.004 \\
\hline 12 & $\begin{array}{l}\text { Being in crowded places (shopping centers, schools, public trans- } \\
\text { port, social activity areas, etc.) worries me during a disaster. }\end{array}$ & 0.708 & -0.025 & -0.059 \\
\hline 13 & $\begin{array}{l}\text { I am worried that I may not be accessed within a short time during a } \\
\text { possible disaster. }\end{array}$ & 0.764 & 0.064 & -0.105 \\
\hline 14 & $\begin{array}{l}\text { The possibility of not being able to accessed by search and rescue } \\
\text { teams after a possible disaster worries me. }\end{array}$ & 0.832 & 0.054 & -0.114 \\
\hline 15 & $\begin{array}{l}\text { The thought of not being able to get enough support (physical, psy- } \\
\text { chological, housing) after a possible disaster worries me. }\end{array}$ & 0.808 & 0.011 & -0.082 \\
\hline 16 & $\begin{array}{l}\text { I am afraid of experiencing communication problems with relatives } \\
\text { after a potential disaster. }\end{array}$ & 0.704 & 0.012 & -0.120 \\
\hline 17 & $\begin{array}{l}\text { The fact that social awareness increases only during disaster times is } \\
\text { worrisome. }\end{array}$ & 0.543 & 0.059 & -0.032 \\
\hline 18 & I think I am prepared for a potential disaster. & -0.071 & 0.301 & 0.561 \\
\hline 19 & $\begin{array}{l}\text { I back up my personal information and documents in case of expo- } \\
\text { sure to a disaster. }\end{array}$ & 0.021 & 0.213 & 0.678 \\
\hline 20 & We prepared family disaster plan against a possible disaster. & -0.084 & 0.092 & 0.865 \\
\hline 21 & I have a disaster and emergency bag. & -0.077 & 0.058 & 0.812 \\
\hline 22 & $\begin{array}{l}\text { We took individual measures, such as fire extinguishers, at home } \\
\text { where I live with my familiy. }\end{array}$ & -0.045 & 0.056 & 0.761 \\
\hline 23 & $\begin{array}{l}\text { I have the required knowledge and training to protect myself during } \\
\text { disasters. }\end{array}$ & -0.095 & 0.275 & 0.688 \\
\hline 24 & I can communicate correctly and accurately in case of an emergency. & -0.047 & 0.351 & 0.545 \\
\hline \multicolumn{2}{|c|}{ Eigenvalues } & 4.831 & 4.080 & 3.802 \\
\hline \multicolumn{2}{|c|}{$\%$ of Variance } & 21.004 & 17.738 & 16.530 \\
\hline \multicolumn{2}{|c|}{ Cumulative \% } & 21.004 & 38.743 & 55.273 \\
\hline
\end{tabular}

To test the factor structure obtained by the EFA, CFA was conducted. The fit indices for construct validity in the CFA are shown in Table 3. The root mean square error of approximation, Non-normed fit index and comparative fit index indicate a good fit, whereas the other indices indicate an acceptable fit. Further, Graph
1 shows the factor structure: $\chi^{2}=320.40$ and $\mathrm{df}=227$. The value of chi-squared divided by degrees of freedom (Chi-square/df) is 1.41, where any chi-squared/df ratio less than 2 indicates an excellent fit (Tabachnick \& Fidell, 2007). According to the fit indices, a three-factor model fits the data adequately. 
Table 3: Goodness of fit indices for the data set (Schermelleh-Engel et al., 2003).

\begin{tabular}{|c|c|c|c|}
\hline Fit Measure & Good Fit & Acceptable Fit & Goodness of Fit Statistics \\
\hline RMSEA & $0 \leq \mathrm{RMSEA} \leq 0.05$ & $0.05<\mathrm{RMSEA} \leq 0.08$ & 0.048 \\
\hline $\mathrm{NFI}$ & $0.95 \leq \mathrm{NFI} \leq 1$ & $0.90 \leq \mathrm{NFI}<0.95$ & 0.920 \\
\hline $\mathrm{NNFI}$ & $0.97 \leq \mathrm{NNFI} \leq 1$ & $0.95 \leq \mathrm{NNFI}<0.97$ & 0.980 \\
\hline $\mathrm{CFI}$ & $0.97 \leq \mathrm{CFI} \leq 1$ & $0.95 \leq \mathrm{CFI}<0.97$ & 0.980 \\
\hline SRMR & $0 \leq \mathrm{SRMR} \leq 0.05$ & $0.05<\mathrm{SRMR} \leq 0.10$ & 0.061 \\
\hline GFI & $0.95 \leq \mathrm{GFI} \leq 1$ & $0.90 \leq \mathrm{GFI}<0.95$ & 0.880 \\
\hline AGFI & $0.90 \leq \mathrm{AGFI} \leq 1$ & $0.85 \leq \mathrm{AGFI}<0.90$ & 0 \\
\hline
\end{tabular}

RMSEA=Root Mean-Square Error of Approximation; NFI=Normed Fit Index; NNFI=Nonnormed Fit Index; CFI=Comparative Fit Index; SRMR=Standardized Root Mean Square Residual; GFI=Goodness-of-Fit Index; AGFI=Adjusted Goodness-of-Fit Index.

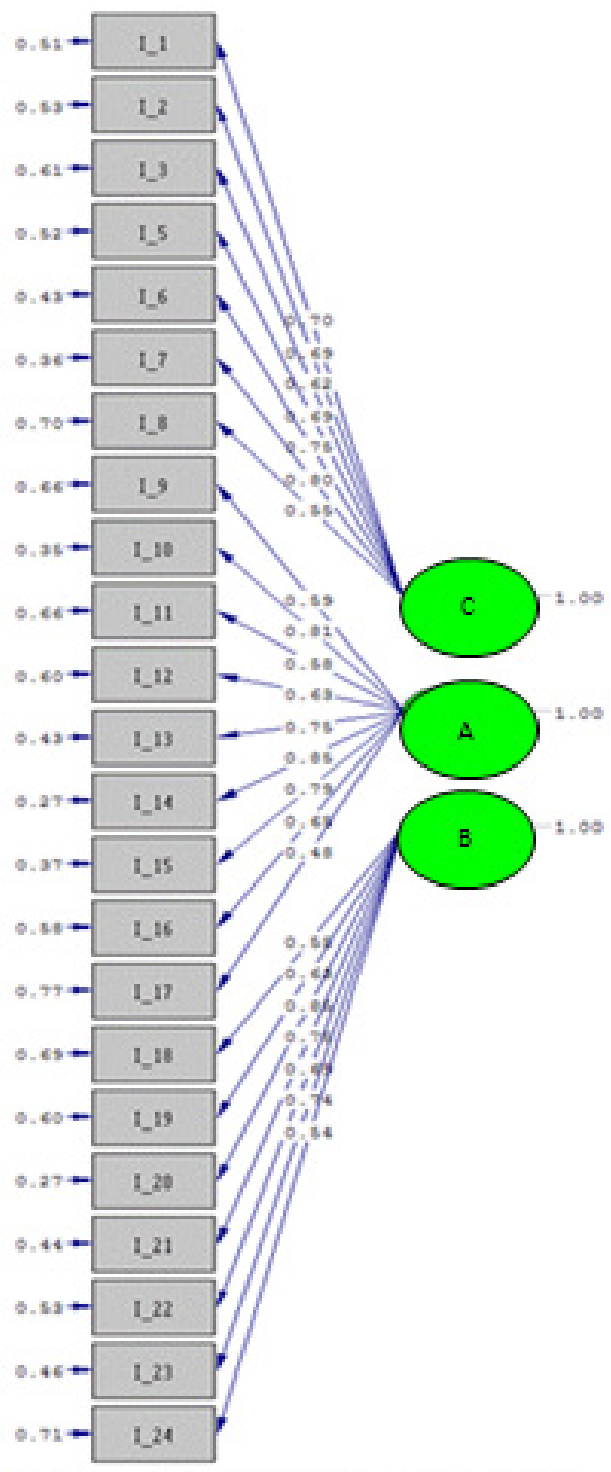

Chi-square=320.40, df=227, p-value=0.00004, sutseA=0.048

Graph 1. Confirmatory factor analysis for students' attitudes towards disasters ( $A=$ Affective, $B=$ Behavioural, C= Cognitive). 
Table 4 shows the item numbers, means, standard deviations, and Cronbach's alpha values for each subscale, as well as the results of a repeated measure ANOVA. The affective component is at a high level ( $\bar{X}$ $=3.71$ and $S D=0.89)$, when the cognitive and behavioural dimensions are under the moderate level $(\bar{X}=$ 2.91 and $\mathrm{SD}=0.83 ; \overline{\mathrm{X}}=2.25$ and $\mathrm{SD}=0.89$ ). Cronbach's alpha values for the subscales are 0.868 for cognitive, 0.836 for affective and 0.852 for behavioural dimensions, indicating high-reliability statistics.

To test whether the factors demonstrate a significant difference due to gender or the study programme, an independent samples t test and a one-way ANOVA were conducted, respectively. The test results are given in Table 5 .
According to the independent samples $t$ test, there is a significant difference in the affective and behavioural factors between male and female participants. However, there is no significant difference in the cognitive factor. The level of affective attitude is higher in females ( $\bar{X}=3.89$ ) than in males ( $\bar{X}=3.43$ ). Conversely, the level of behavioural attitude is higher in males $(\bar{X}=2.44)$ than in females $(\bar{X}=2.12)$.

Results from a comparison of the dimensions of attitude of the students related to their study programmes are shown in Table 5. The students' study programmes influence both affective and behavioural dimensions. The level of affective attitude is higher for students of health sciences ( $\bar{X}=3.83$ ) than for those of natural sciences $(\bar{X}=3.61)$. The level of behavioural attitude is higher for students of natural sciences $(\bar{X}=$ 2.39) compared with those of the other programmes.

Table 4. The item numbers, means, standard deviations and reliability statistics for each factor and the results of repeated measure ANOVA.

\begin{tabular}{|l|c|c|c|c|c|c|}
\hline Factors & Item Number & Mean & SD & \multirow{2}{*}{ F } & p & $\begin{array}{c}\text { Cronbach's } \\
\text { Alpha }\end{array}$ \\
\hline Cognitive & 7 & $2.91^{\mathrm{b}}$ & 0.83 & & & 0.868 \\
\hline Affective & 9 & $3.71^{\mathrm{a}}$ & 0.89 & \multirow{3}{*}{639.962} & \multirow{3}{*}{$<0.001$} & 0.836 \\
\cline { 1 - 4 } Behavioural & 7 & $2.25^{\mathrm{c}}$ & 0.89 & & & 0.852 \\
${$\cline { 1 - 4 }$} }$ & 23 & 3.02 & 0.56 & & & 0.810 \\
\hline
\end{tabular}

$a, b, c$ : The difference between means having different letters is significant $(p<0.05)$.

Table 5. The results of independent samples t test and one-way ANOVA.

\begin{tabular}{|c|c|c|c|c|c|c|c|}
\hline \multirow{2}{*}{ Variables } & \multirow{2}{*}{ Groups } & \multicolumn{2}{|c|}{ Cognitive } & \multicolumn{2}{|c|}{ Affective } & \multicolumn{2}{|c|}{ Behavioural } \\
\hline & & Mean $\pm S D$ & $\mathrm{p}$ & Mean \pm SD & $\mathrm{p}$ & Mean \pm SD & $\mathrm{p}$ \\
\hline \multirow{2}{*}{ Gender } & Male & $2.96 \pm 0.86$ & \multirow{2}{*}{0.136} & $3.43 \pm 0.89$ & \multirow{2}{*}{$<0.001$} & $2.44 \pm 0.85$ & \multirow{2}{*}{$<0.001$} \\
\hline & Female & $2.87 \pm 0.80$ & & $3.89 \pm 0.83$ & & $2.12 \pm 0.89$ & \\
\hline \multirow{3}{*}{ Type of program } & Natural Science & $2.96 \pm 0.82$ & \multirow{3}{*}{0.279} & $3.61 \pm 0.89^{\mathrm{b}}$ & \multirow{3}{*}{$<0.049$} & $2.39 \pm 0.84^{\mathrm{a}}$ & \multirow{3}{*}{$<0.01$} \\
\hline & Social Science & $2.84 \pm 0.87$ & & $3.69 \pm 0.86^{\mathrm{ab}}$ & & $2.24 \pm 0.92^{\mathrm{b}}$ & \\
\hline & Health Science & $2.91 \pm 0.77$ & & $3.83 \pm 0.88^{a}$ & & $2.12 \pm 0.87^{b}$ & \\
\hline
\end{tabular}

$a, b$ : The difference between groups having different letters is significant $(p<0.05)$.

\section{DISCUSSION}

The main purpose of this study is to develop a new disaster attitude scale. The common feature of scale development studies is to produce a tool that will measure a certain phenomenon in terms of distinct dimensions and items. Likert type scales (Likert, 1932) are generally used in scale development studies. In this framework, unlike the few relevant studies in literature, this study presents a disaster attitude scale consisting of three dimensions (affective, behavioural and cognitive) and 23 items developed to determine attitudes towards disasters. By using this new disaster attitude scale, which has been found to be both reliable and valid, the attitudes of university students living in Afyonkarahisar, a high-risk earthquake area in Turkey, towards disasters have been determined. Some important results obtained from the study are as follows: University students' attitudes in the affective dimension were higher than cognitive and behavioural dimensions. This means that despite the high levels 
of fear and anxiety of the individuals, the scores for the cognitive dimension that includes the thoughts and the beliefs, and the behavioural dimension that includes readiness and preventive behaviours are not at the required level. Additionally the cognitive dimension, representing information and beliefs about disasters, did not differ based on gender or study programme. However, there were differences in attitudes in the affective and behavioural dimensions associated with gender and study programme.

The scores for the affective dimension showed that female students had more fear, anxiety and worry about disaster and less disaster preparedness than male students, as reported previously by a study on different communities of Lovekamp (2006). Despite a high level of anxiety and fear among students, there was a lack of action, such as taking measures towards disasters. It should be noted that this was more apparent in female students than in males. Previous studies that investigated both gender and disasters demonstrated important results regarding women: both during and after disasters, women are more likely to be affected than men (Croson \& Gneezy, 2009; Neumayer \& Plümper, 2007).

When attitudes of students of natural sciences were compared with attitudes of students of health sciences, a significant difference in the affective dimension was detected. It can be said that the levels of anxiety and fear of students in the health sciences were higher than those in students of other programme. Moreover, there was a difference between the attitudes of students of natural sciences and the attitudes of students of other programmes in terms of the behavioural dimension: students of natural sciences had relatively higher scores in behavioural attitude. In fact, since students studying health sciences in order to provide services to public health are thought to have certain qualities such as managing emergency situations, they were expected to score lower in the affective dimension compared to those studying in other programs (natural and social sciences). Also, they were expected to score higher in the behavioural dimension because they were expected to be superior in terms of sensitiveness and responsibility. This contradiction can be attributed to several factors such as the deficiencies and shortcomings in terms of creating an awareness on community health, which result from the fact that the issues of protecting and promoting health are approached in a rather individualized manner within the process of education in health sciences.

The results of the analysis show that although disasters have destructive and agonizing impacts on the environment as well as on people's lives, attitudes towards disasters are not at the required level according to these measurements made at the local level. In a study, Ozkazanc and Yuksel (2015) aimed to determine the level of disaster awareness and disaster sensitivity of students in Turkey; their study revealed similar results. To cope with this problem, it is necessary to produce and implement policies in the scope of preparation for a possible crisis.

As a result, this particular study, which provides a valuable insight and contribution into the attitudes of undergraduate students, suggests the use of popular social media tools among young people to increase disaster awareness of university students. Short videos and animations posted on social media channels can make a significant contribution to attitude change. These videos and animations should take into consideration the short attention span of the target audience. The drills to be held during the time periods covering the course and library times, and the trainings to be organized afterwards, will raise awareness, help develop disaster culture and a reflex.

In addition to contributing to literature, the results obtained from this study are important data sources for institutions and organizations concerned with disasters. Besides, using the present scale, it will be possible for different researchers to determine the attitudes of people in different sample groups (in different geographies, countries, cultures, individuals with different socio demographic characteristics) towards disasters. The scale developed in this study is also an important first step in the development of individuals' awareness on and readiness to disasters.

\section{ETHICAL STATEMENT}

Permission for the study was granted by the Scientific Research and Publication Ethics Committee of Afyon Kocatepe University in May 2016; the data were collected between May and June 2016. Participants were informed that the survey aimed to collect data for a scientific study and volunteers willingly participated in the study. 


\section{REFERENCES}

Ahayalimudin, N., \& Osman, N. N. S. (2016). Disaster management: Emergency nursing and medical personnel's knowledge, attitude and practices of the East Coast region hospitals of Malaysia. Australasian Emergency Nursing Journal, 19(4), 203-209.

Baytiyeh, H., \& Öcal, A. (2016). High school students' perceptions of earthquake disaster: A comparative study of Lebanon and Turkey. International Journal of Disaster Risk Reduction, 18, 56-63.

Bhat, B. A., Anees, S-U-M, Geelani, S. N. Z., Nusrat, Jan, I., \& Zargar, B. A. (2017). A study on disaster awareness and preparedness among college students in district Ganderbal of Kashmir valley. International Journal for Science and Advance Research in Technology, 3(12), 156-159.

Croson, R., \& Gneezy, U. (2009). Gender differences in preferences. Journal of Economic Literature, 47(2), 448-474.

Dalkey, N., \& Helmer, O. (1963). An experimental application of the Delphi method to the use of experts. Management Science, 9(3), 458-467.

Dooley, D., Catalano, R., Mishra, S., \& Serxner, S. (1992). Earthquake preparedness: predictors in a community survey. Journal of Applied Social Psychology, 22(6), 451-470.

Edwards, A. L. (1983). Techniques of attitude scale construction. Ardent Media.

Grimm, A., Hulse, L., Preiss, M., \& Schmidt, S. (2014). Behavioural, emotional, and cognitive responses in European disasters: results of survivor interviews. Disasters, 38(1), 62-83.

Honda, A., Wiwattanapantuwong, J., \& Abe, T. (2014). Japanese university students' attitudes toward the Fukushima nuclear disaster. Journal of Environmental Psychology, 40, 147-156.

IFRC (2015). World Disasters Report 2015. International Federation of Red Cross and Red Crescent Societies, Geneva, Switzerland. Retrieved from https://ifrc-media.org/interactive/wp-content/ uploads/2015/09/1293600-World-Disasters-Report-2015_en.pdf

Junn, E. N., \& Guerin, D. (1996). Factors related to earthquake preparedness among child care professionals: Theory and policy implications. International Journal of Mass Emergencies and Disasters, 14(3), 343-359.

Likert, R. (1932). A technique for the measurement of attitudes. Archives of Psychology, 22, 5-55.
Lindell, M. K., \& Perry, R. W. (2003). Communicating environmental risk in multiethnic communities. Sage Publications.

Lindholm, J., Carlson, T., Djupsund, G., Gögväg, J., \& Strandberg, K. (2015). Citizens' emotional and cognitive responses to focusing events--an Experimental study. International Journal of Mass Emergencies and Disasters, 33(3), 407-427.

Lovekamp, W. E. (2006). Gender, race/ethnicity and social class differences in disaster preparedness, risk and recovery in three earthquake-stricken communities (Doctoral dissertation). Southern Illinois University Carbondale, United States - Illinois.

Maltby, J., Day, L., \& Macaskill, A. (2010). Personality, individual differences and intelligence. Harlow: Pearson Education.

NEA (National Education Association) (1965). Sampling and statistics handbook for surveys in education. Washington, DC: National Education Association Press.

Neumayer, E., \& Plümper, T. (2007). The gendered nature of natural disasters: The impact of catastrophic events on the gender gap in life expectancy, 1981-2002. Annals of the Association of American Geographers, 97(3), 551-566.

Olson, J. M., \& Zanna, M. P. (1993). Attitudes and attitude change. Annual Review of Psychology, 44(1), 117-154.

Ozkazanc, S., \& Yuksel, U. D. (2015). Evaluation of disaster awareness and sensitivity level of higher education students. Procedia-Social and Behavioral Sciences, 197, 745-753.

Pekez-Pavliško, T., Račić, M., \& Jurišić, D. (2018). A questionnaire study on the attitudes and previous experience of Croatian family physicians toward their preparedness for disaster management. Bulletin of Emergency and Trauma, 6(2), 162-168.

Qi, Z., Jing-yi, L., \& Jing-bo, Z. (2003). Study on index system of assessment of public disaster perception in the western China. Chinese Geographical Science, 13(3), 284-288.

Rosenberg, M. J., \& Hovland, C. I. (1960). Cognitive, affective, and behavioral components of attitudes. Attitude organization and change: An analysis of consistency among attitude components, 3, 1-14.

Rottach, P. (n.d.) Background and Components of Disaster Risk Reduction. Retrieved from http:// 
www.preventionweb.net/files/24122_24122backgroundcomponentsofdrractdi.pdf

Schermelleh-Engel, K., Moosbrugger, H., \& Müller, H. (2003). Evaluating the fit of structural equation models: Tests of significance and descriptive goodness-of-fit measures. Methods of Psychological Research Online, 8(2), 23-74.

Smith, M. B. (1968). Attitude change. International encyclopedia of the social sciences. Crowell Collierand Mac Millan.

Tabachnick, B. G., \& Fidell, L. S. (2007). Using multivariate statistics. Boston: Pearson/Allyn \& Bacon.

Tavan, H., Menati, W., Azadi, A., Sayehmiri, K., \& Sahebi, A. (2016). Development and validation of a ques- tionnaire to measure Iranian nurses' knowledge, attitude and practice regarding disaster preparedness. Journal of Clinical and Diagnostic Research, 10(8), IC06-IC09.

Terpstra, T. (2011). Emotions, trust, and perceived risk: Affective and cognitive routes to flood preparedness behavior. Risk Analysis, 31(10), 1658-1675.

Tierney, K. J., Lindell, M. K., \& Perry, R. W. (2001). Facing the unexpected: Disaster preparedness and response in the United States. Joseph Henry Press.

Zanna, M. P., \& Rempel, J. K. (1988). Attitudes: A new look at an old concept. The Social Psychology of Knowledge, 8, 315-334. 